zeća. Mjerenje učinka koje organizacije stvaraju i hvatanje stvorene društvene vrijednost još su uvijek među ključnim izazovima s kojima se treći sektor suočava. »Euclid Summit« je naglasio da taj sektor ima potrebu i zadaću kontinuirano razvijati svoje sposobnosti kako bi pozitivnom društvenom promjenom mogao utjecati na svijet koji se brzo mijenja i koji je opterećen novim socijalnim rizicima.

Danijel Baturina

Studijski centar socijalnog rada, Pravni fakultet Sveučilišta u Zagrebu

DOI: $10.5613 /$ rzs.46.1.7

\section{Međunarodna konferencija »Religion and Non-Religion in Contemporary Societies. Theoretical, Empirical and Methodological Challenges for Research in Central and Eastern Europe and Beyond"}

Zadar, 21.-24. travnja 2016.

U organizaciji ISORECEA-e (International Study of Religion in Eastern and Central Europe Association) i Istraživačke mreže za sociologiju religije (Sociology of Religion Research Newtork) Europskoga sociološkog društva te $\mathrm{u}$ suradnji s Odjelom za sociologiju Sveučilišta u Zadru i Hrvatskim sociološkim društvom, održana je međunarodna kon- ferencija »Religion and Non-Religion in Contemporary Societies. Theoretical, Empirical and Methodological Challenges for Research in Central and Eastern Europe and Beyond « u Zadru od 21. do 24. travnja 2016. godine. To je ujedno i 12. konferencija ISORECEA-e, koja je među redovnim, ali i novim, izlagačima i sudionicima već stekla poštovanja vrijednu tradiciju i velik ugled.

U predgovoru Knjige sažetaka njezini urednici i organizatori konferencije Dinka Marinović Jerolimov i Siniša Zrinščak ističu da se u pripremi teme konferencije željelo naglasiti »međuigru povijesnih, kulturnih i političkih čimbenika i događaja koji su pridonijeli činjenici da su u suvremenim društvima jednako važni procesi povezani s religijom kao i nereligijom«. Napominju i da "nereligija« kao pojam i proces još uvijek ne dobiva dovoljno teorijske razrade i empirijske pozornosti, uključujući društva poput bivših socijalističkih zemalja u kojima je ateizam predstavljao vladajuću ideologiju. Urednici osobito ističu izniman interes autora za sudjelovanje na konferenciji, što je rezultiralo s 92 izlaganja u (su)autorstvu 111 izlagača, odnosno 101 sudionikom konferencije iz 20 europskih zemalja, Kanade, Sjedinjenih Američkih Država, Južne Koreje, Indije i Pakistana.

U sklopu konferencije održana su dva plenarna izlaganja. Lois Lee, istraživačica s Instituta za napredne studije (University College London), govorila je na temu pod naslovom »Secularisation without the secular: Understanding religion and nonreligious in a 
postsecular age« (»Sekularizacije bez sekularnog: razumijevanje religije i nereligijskog u postsekularnom dobu«), a profesor Marjan Smrke iz Centra za kulturne i religijske studije Fakulteta za društvene znanosti iz Ljubljane održao je predavanje »Toward a sociology of irreligion in post-Yugoslav states« (»Prema sociologiji ireligije u državama bivše Jugoslavije«).

Ostala izlaganja tijekom četiri dana konferencije obuhvaćala su različite teorijske i empirijske pristupe temi religije i nereligije kroz mnoštvo različitih aspekata poput religijskog pluralizma, položaja religijske manjine i većine, uloge ateizma i novih religijskih pokreta, odnosa religije i ekonomije, obrazovanja, socijalne države, javnih politika, obitelji, mladih, javnog prostora i ekologije, zatim povezanosti religijskog i drugih identitetskih odrednica poput spola/roda te etničke i nacionalne pripadnosti, simboličke dimenzije religijske pripadnosti te posebnih slučajeva pojedinih religija i zemalja, uključujući vrijedne doprinose izlagača iz Hrvatske o ulozi religije u hrvatskom društvu.

Osim sadržajno, organizacija konferencije $u$ izvedbenom smislu, od odabira grada i prostora do dodatnih, fakultativnih, sadržaja, također je bila izvrsna. Razmjerno ležeran tijek skupa, koji je bio rezultat prirodnog okruženja koje pruža Zadar i odlične organizacije konferencije, omogućio je bolje upoznavanje sudionika i razmjenu ideja kroz manje formalna druženja. Organizatorima upućujemo čestitke na uspješnoj konferenciji, inspirativnoj za budući rad vezan uz iznimno aktualnu tematiku koju je bila u žarištu skupa.

Tijana Trako Poljak Odsjek za sociologiju, Filozofski fakultet Sveučilišta u Zagrebu 